\title{
Common Space in Post-Socialist Housing in Serbia: The Comparison of the Preferences of the Two New Condominium Building Dwellers in the City of Sremska Mitrovica
}

\section{Aleksandra Dukić}

Associate professor, Dr, University of Belgrade, Faculty of Architecture Bulevar kralja Aleksandra 73/2, 11000 Belgrade, Serbia

\section{Branislav Antonić*}

Researcher-assistant and PhD student, University of Belgrade, Faculty of Architecture Bulevar kralja Aleksandra 73/2, 11000 Belgrade, Serbia

*Corresponding author: antonic83@gmail.com

$\Gamma$ erossef http://dx.doi.org/10.5755/j01.sace.17.4.15408

After the fall of the Berlin Wall, all socialist societies in Europe entered a post-socialist transitional period. Nevertheless, their transit through the period has been different. Due to the Yugoslav crisis in the 1990s, Serbian transition has been both postponed and rough. This state, known as a "blocked transformation", has prompted many unordinary situations, where some new capitalist phenomena have emerged side by side with the preservation of old, socialist elements.

In the case of Serbian housing, the construction of new multi-family housing in the form of a condominium is such an example. The first private investments of this sector began in the early 1990s and boomed during the 2000s. The system of solidarity funds for housing construction, preserved from socialist Yugoslavia, existed up to the early 2000s. Although both types of housing construction have existed simultaneously, they have had different features, most notably the selection of new apartment dwellers. The proposed research aims to understand if this difference between the two mentioned types of new multi-family housing has influenced the newly formed communities in these buildings - how dwellers function as a community? The research "polygon" comprises two buildings in the city of Sremska Mitrovica, Serbia. The first example is the last multi-family building built by solidarity funds; the second one was built at the same time, but it was a private-investment project. The method used in the research is a survey that is shaped to cover the main issues about locally named "community spaces" - common spaces in condominium buildings and around it. The subjects of the survey are the dwellers of both buildings. The results of the survey are expected to present a noticeable difference in the opinions of the respondents. Using this method, this research intends to clarify if different procedures of the
JSACE 4/17

Common Space in Post-Socialist Housing in Serbia: The Comparison of the Preferences of the Two New Condominium Building Dwellers in the City of Sremska Mitrovica

Received 2016/07/28

Accepted after revision 2016/12/07

\section{ktu \\ 1922}

Journal of Sustainable Architecture and Civil Engineering Vol. 4/ No. 17 / 2016 pp. $45-59$

DOI 10.5755/j01.sace.17.4.15408 (c) Kaunas University of Technology 
selection of dwellers influence the dwellers' opinions and behaviours towards collective places. This clarification will be the foundation of new recommendations to improve the current state and regulation in condominium housing in Serbia.

KEYWORDS: housing, post-socialist transition, Serbia, survey.

Post-socialist transition has been the major phenomenon in Central and Eastern Europe in the last 25 years (Borén \& Gentile, 2007; Pickvance, 2008). Following the fall of the Berlin Wall in 1989, all former socialist societies have faced fast and profound changes in all spheres (political, economic, social, cultural, etc) towards globalization (Hamilton, Dimitrovska Andrews, Pichler-Milanović 2005). These changes were sudden and very intensive - they can be commonly described as a "shock" for young post-socialist societies (Stenning, 2005; UN Habitat, 2013). Furthermore, these changes have not been the same; every post-socialist society has had a different post-socialist transition regarding its "old socialist heritage" and new post-socialist circumstances (Hamilton, Dimitrovska Andrews, Pichler-Milanović 2005; Hirt, Stanilov, 2009). Therefore, post-socialist transition cannot be described as one "entity". It is rather a myriad of different paths, transformations and patterns with some common characteristics.

The previous statement is perfectly illustrated by the case of Serbia. Post-socialist transition in Serbia has been both postponed and rough due to the Yugoslav crisis in the 1990s (Antonić, 2016). Furthermore, Serbia (then a part of SR Yugoslavia) was the last country in the region to open towards globalization - it happened in 2000. This unique situation during the 1990s is locally known as a "blocked transformation" (Petrović, 2004). It produced some unique and unordinary features during this time, where some elements of old socialist system met with and existed side by side with the newly introduced capitalist elements.

One of these unique features is noticeable in multi-family housing in the form of a condominium in post-socialist Serbia. Generally, housing is a significant topic among post-socialist scholars due to a very noticeable transformation of housing sectors during this time (Enyedi, 1995; Sailer-Fliege 1999; Tsenkova, Polanska, 2014). During socialist era, housing was developed in line with the principles of collectivism (Hirt, Petrović, 2011). Thus, it has been vulnerable to new, "capitalist" conditions - the topics of residential segregation, gentrification and urban poverty in housing inevitably play an important role in the main research of post-socialist urban context (Vujović, Petrović, 2005; Hirt, Stanilov, 2009; Lux and Sunega, 2014).

Nevertheless, national specificities have dominated the housing sector of (post-)socialist countries (Węctawowicz, 2013). This is very true in the case of Serbia - multi-family housing in both former socialist Yugoslavia and post-socialist Serbia have distinctive characteristics. The former "second" Yugoslavia (1945-1991) was a somewhat specific socialist system having more contacts with the West (Pichler-Milanović, 1999; Hirt, Petrović, 2011). It had thereby more freedom at all levels, which resulted in planned and market economy merging in a very unique model. However, housing was very important for the socialist state and some basic elements of socialist ideology were strictly implemented in housing - newly-built multi-family housing in Yugoslavia was publicly-owned, as was also the case of other socialist countries (Tsenkova, Z.Nedović-Budić, 2006). It was known as "housing with tenant rights" (Milić, 2006).

But, housing construction was very innovative for the socialist world; semi-capitalist model was introduced through the institution of the funds for solidarity housing construction (short: Solidarity funds). The model was based on the formation of market between different state companies; one of them was a construction company and a flats' seller and the other were buyers from various fields. The model was developed in the 1960s, reaching its peak in the 1970s and the 1980s (Petrović, 2004) and it was pretty prosperous during these two decades - almost $50 \%$ of the total multi-family housing stock in Serbia was built during these 20 years (Jovanović Popović et al, 
2013). At the same time, this system was fully decentralized, giving the main role to local level that was able to manage local housing policy through the creation of specific local housing standards and planning tools (Hirt, Stanilov, 2009). Special housing agencies were established to manage this process (BHA, no date). As a result, the former Yugoslavia witnessed a system of housing decentralization and a semi-formed housing market that was noticeably far away from the "simple" housing provision by the state and the obvious centralization of housing policy. Such a scenario was typical for many socialist countries.

This unique system existed until the 2000s, i.e. side by side with the appearance of the new capitalist housing construction, developed as private investments (Tsenkova, 2005). Actually, private constriction in multi-family housing boomed in the 2000s, when solidarity funds officially disappeared. But, private initiative in housing construction has arisen in the early 1990s, caused by the problems produced by the collapse of the socialist Yugoslavia. The most notable one was the overall withdrawal of the public sector from housing construction (Hirt, Petrović, 2011). In fact, it was urged by mass-privatization of old housing stock after the Law on housing was passed in 1992. This was a common approach throughout post-socialist area, initially well-accepted by both the state (old owner) and the dwellers (new owners) (Tsenkova 2000, Petrović 2004; Petrović 2009). Despite the fact that it was also supported by respectable international financial bodies, such as World Bank or International Monetary Fund (Kemeny, 1995; Hegedüs, 2013), mass-privatization in post-socialist housing has been implemented without the necessary local or regional customisations (Petrović, 2009). Knowing that more than $98 \%$ of housing in present-day Serbia is in private ownership (Pichler-Milanović, 1999; Petrović, 2004; Hirt, Stanilov, 2009; Lux and Sunega, 2014), the market has been the main supplier of new housing stock in the last 25 years. This situation has produced the observable "blossom" of new housing construction. And, housing sector has proved to be one of the most profitable ones in the country (Mojović, Žerjav, 2011). More precisely, this has been the case with multi-family multi-storey buildings, which are the most rational type in relation to resources and capacities and it thereby brings a larger profit for the private investors. Taking this in consideration, new/post-socialist multi-family housing represents almost $1 / 4$ of the entire housing stock in Serbia today (Jovanović Popović et al, 2013b).

Despite a 15-year coexistence of older, socialist and newer, capitalist model in multi-family housing construction, these models had different characteristics. One of them was the selection of new flat dwellers. The selection of new dwellers had a noticeable "social" component in the system of solidarity funds in Yugoslavia (Petrović 2004, Milić 2006). For example, this component included the number of members of a households, the number of children, etc. A similar pattern also existed in other socialist countries. On the other hand, new housing is built for the market and thus the only "criteria" for new dwellers is their financial ability to buy a new housing unit (flat).

The aim of this paper is to explore if these different approaches to the selection of dwellers have had a more profound influence on the building of community in certain cases. The aim will be reached through the research of the dwellers' preferences towards common space in two selected residential buildings in the form of a condominium and their nearby open area. This question is certainly an issue for housing, which has a very significant role in the social aspect of an urban place (Smith, 1971). Furthermore, the maintenance and management of all condominiums in post-socialist countries is a critical issue in housing functioning (Pojani, Baar, 2016). This is particularly true in the case of common areas in and around the buildings because they are not easily seen as private property (Bank et al, 1996).

Common space in condominium residential buildings is known as "collective space" (Serb. заједнички простор / zajednički prostor), and is officially named a "collective indivisible ownership" - all owners of the parts of a building have the right of collective ownership of the collective parts and infrastructure of the building (PS, 1980-2005). Therefore, collective ownership is 
a complex issue (Anđelković, 2011). However, this law and other competent legal acts have not treated common areas in detail. Some local acts prescribe just the basic maintenance of collective spaces. Furthermore, the implementation of these legal documents is weak. As a result, common areas in most of the condominiums in Serbia are in poor condition.

In addition to the above mentioned, official statistical data regarding this topic is scarce and usually inaccurate. Therefore, it is not surprising that there is no much relevant research of this topic in Serbia. Taking in consideration the aforementioned deficiencies, innovative approaches to collect and explore appropriate data are inevitable. The method selected for this research is a survey. The subjects in the survey are the dwellers of two multi-family housing buildings built in the early 2000 s in the city of Sremska Mitrovica. These buildings differ on the basis of investments; the first one is the last building built by a solidarity fund in the city; the second one is a typical example of a private-driven investment project.

The different selection of dwellers in both buildings is expected to have an impact on their attitude towards collective space. Consequently, it will be a real sign of how the selection in housing influences further life in the community. In the end, it will be a basis for final recommendations to improve the current state and regulation in multi-family housing. They will specifically target the findings regarding the consolidation and building a new community in condominium residential buildings in Serbia.

The methodology used in this paper is organised in the form of a survey. This method was selected because it is a proper methodological approach for the cases where individual and personal experiences and opinions play an important role. The feature of qualitative estimation of social aspect is very significant for housing - this field is certainly more socially oriented than many other urban functions (Petrović, 2004). A survey-based approach is also very common in housing research. Therefore, the foci of this survey are on individual preferences in housing, which consequently exclude some other users from this research for more accurate results (for example, employees in several commercial units in the second residential building).

Since a survey has been selected as a method, an accompanying questionnaire with 18 questions was composed. The volume and complexity of the questionnaire were tailored so as to be suitable for simple and easy response by the dwellers as laymen. The questionnaire comprises four groups of questions. The first group of questions was "0" questions and it differed from the other groups, i.e. it covered the basic information regarding the dwellers-respondents: their gender, age, the size of their household, and the type of flat ownership. The other three groups were connected to the main topic of the research.

All 18 questions in the questionnaire are organized as closed-ended ones. Almost all of them (except one) are multiple-choice questions, where respondent can opt for one choice. Among them, many questions comprise gradations from strong affirmation to strong negation of the proposed claim (i.e. from strong "yes" to strong "no"). Finally, one question was different from the others; two answers were requested in this question due to a bigger number of given choices ( 8 of them).

Current situation assessment: Both selected multi-storey multi-family buildings are located in the City of Sremska Mitrovica, which is, according to Serbian conditions, a middle-size urban settlement. Being the seat of Srem District, it is a typical regional centre with a variety of functions and built typologies throughout the urban area. Therefore, the size of Sremska Mitrovica enables the existence of different types of Serbian housing. On the other hand, it is not a big city, which simplifies the focus on the most illustrative examples of new housing (Antonić, 2014).

Both residential buildings are selected due to their age; they are both recent projects from the 2000s. It was pointed earlier that these years had been characterised by the "blossom" of the new 
construction of multi-family housing in Serbia. The case of Sremska Mitrovica has followed this trend (Antonić, 2014). The first residential building was built in 2006 and it was the last example of the project built through the institution of solidarity funds in the city. The second one was chosen in relation to the first one. The main difference was that the second one was a typical private-driven project. It was built a few years later, in 2009, which was the last "normal" year before the World economic crisis started to influence the Serbian housing market. But, there have been more than 45 similar private projects in Sremska Mitrovica since 2000 (Antonić, 2014). Therefore, beside their similar age, both chosen examples also have several other essential similarities:

Both buildings are in the form of a free-standing and a fully detached building in a previously formed super-block. It is important to headline that the first characteristic (a free-standing building) is common in post-socialist housing in Serbia - more than $40 \%$ of post-socialist multi-family buildings belong to this type (Jovanović Popović et al, 2013b). However, these buildings have predominantly been built in their separate building plots in a typical urban plot. The location in a super block is pretty rare for new housing due to the lower utilization of the space of the block. Actually, both buildings are the latest ones in their super blocks.

Both buildings have similar number of housing units. The first one comprises 33 units and the second one 37 units. More precisely, the second building initially had more flats (48), but 5 of them were merged in bigger units either during construction or immediately after it. Additionally, 6 of the rest have been transformed for non-residential purposes (an attorney office, 3 agencies, a cosmetics studio, and a pharmacy on the ground floor and without the link to the main corridor of the building).

- Although the second building is generally bigger by volume and area, both building have 6 floors (ground floor +4 "normal" floors + attic floor). The number of floors is maximal for residential construction in the urban area by the acting General urban plan of Sremska Mitrovica (CSM 2009).

The flats in both buildings are similar in size (1-3-room flats with the area of 40-80 $\left.\mathrm{m}^{2}\right)$. This feature is a step towards theoretical assumption of the similar social structure of the dwellers.
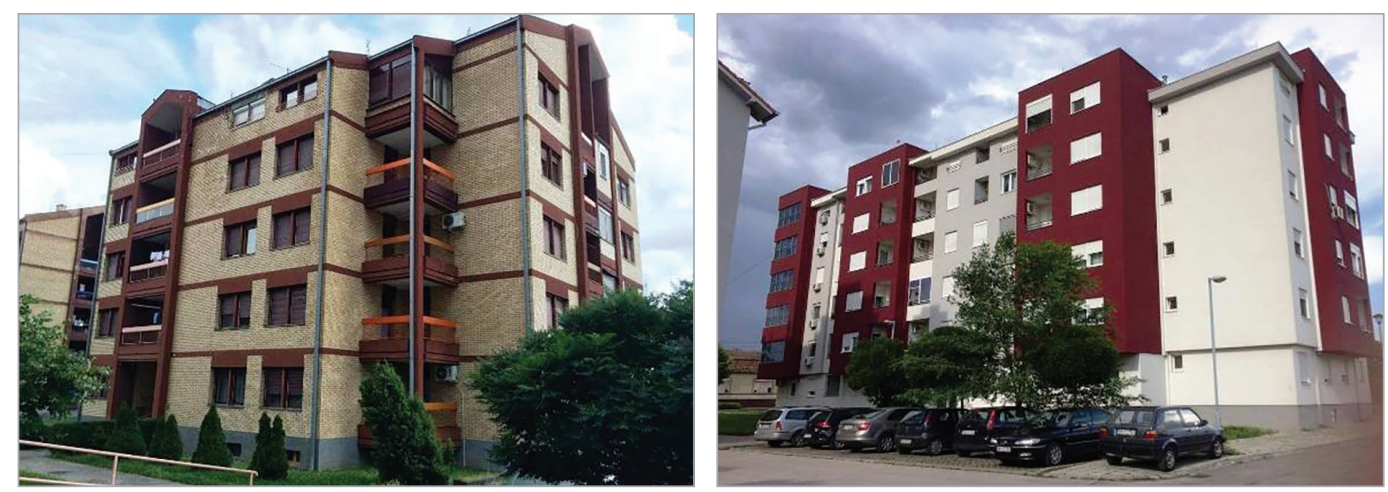

Both buildings are the same regarding collective space in the construction and around it. Thus, aside inevitable space for this type of residential buildings, both of them have lifts inside and a mix of green and parking space around them.

Indoor collective spaces are typical for this type of buildings. They are minimalistic by looks and amenities. There is no special heating or cooling system - both are provided indirectly by flats, which almost encircle them. The only significant infrastructural element is artificial lightening.
Fig: 1, 2

Two selected residential buildings in Sremska Mitrovica, Serbia (source: Branislav Antonić) 


\section{Fig. 3, 4, 5, 6 \\ Vestibule and the main corridor in the first building and vestibule and staircases with a lift in the background in the second building (source: \\ Branislav Antonić)}

Fig. 7

Position of both buildings in urban built-up area (source: Branislav Antonić)
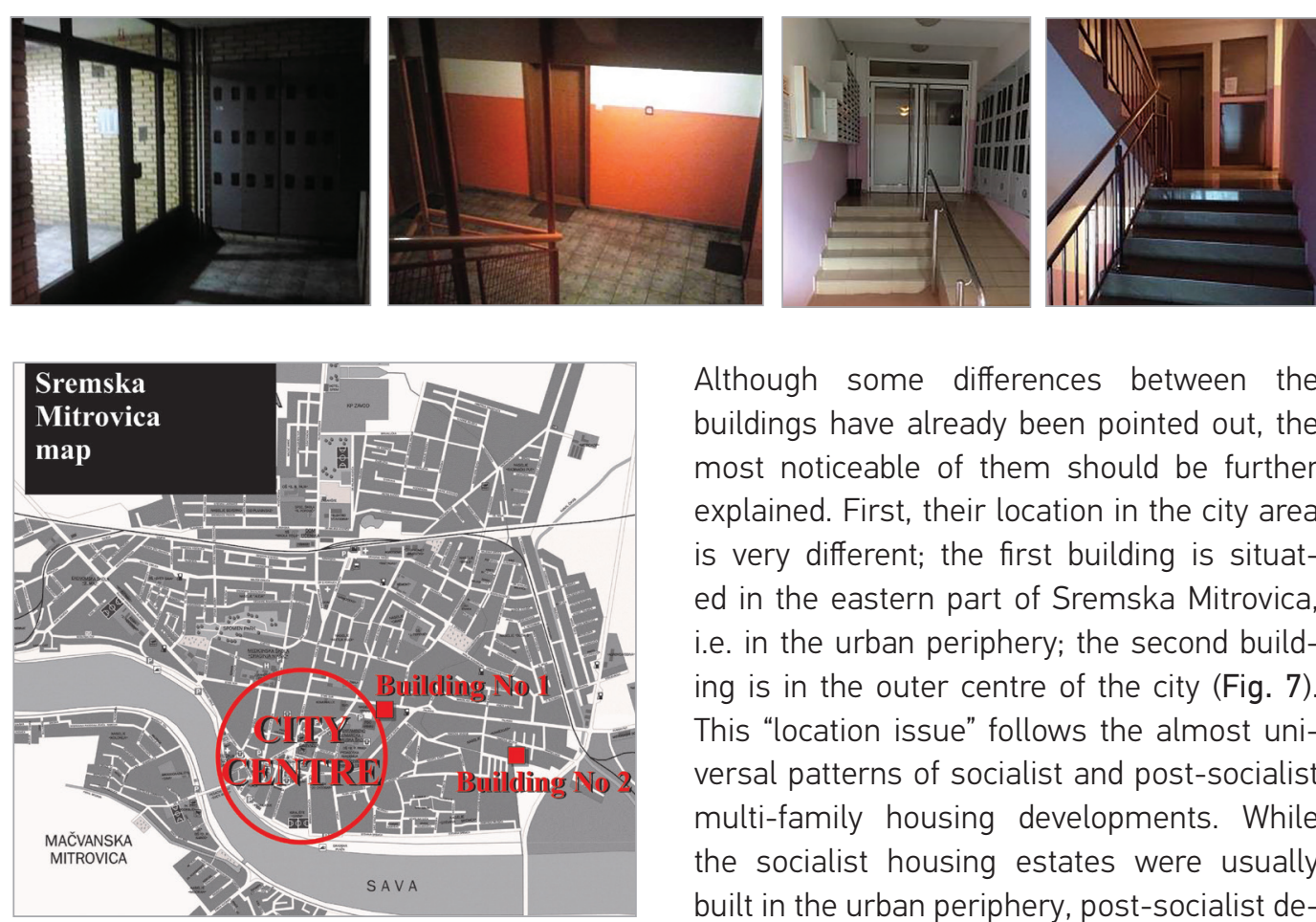

Although some differences between the buildings have already been pointed out, the most noticeable of them should be further explained. First, their location in the city area is very different; the first building is situated in the eastern part of Sremska Mitrovica, i.e. in the urban periphery; the second building is in the outer centre of the city (Fig. 7). This "location issue" follows the almost universal patterns of socialist and post-socialist multi-family housing developments. While the socialist housing estates were usually built in the urban periphery, post-socialist de-

velopment has often been situated in central areas, making paths for urban regeneration and renewal (Petrović, 2009). A better location in the city area is probably the reason why there are non-residential facilities in the second building.

Side by side with the presented characteristics of the residential buildings as wholes, there are also similarities and differences at the level of flat design. For this research, it will just be mentioned that the internal organization of flats and the related issues (natural lightening, room size and dimensions, etc.) are more qualitative in the first building.

Basic data regarding respondents: Intending to encompass as many respondents as possible, the survey was carried out during three afternoons, when dwellers are usually at home: on June $1^{\text {st }}$ (Tuesday), June $3^{\text {rd }}$ (Friday), and June $5^{\text {th }}$ (Sunday) 2016. There were 56 respondents in total (27 respondents in the first building and 29 of them in the second one). The profile of the respondents in both buildings can be portrayed based on the information in " 0 " questions:

- The ratio between genders was pretty equal in both cases. In the first building (hereinafter: I), "male/female" ratio was 52\%/48\% and in the second one (hereinafter: II) it was 45\%/55\%.

_ Taking in account the respondents' age, first of all it should be emphasised that minors under the age of 18 were excluded from the survey due to possible misunderstandings of the proposed questions. The survey showed that almost all respondents (or 98\%) were adults of the working age (18-65 years old). Just one person in the second building was in retirement age, i.e. older than 65. This fact clearly proves that new multi-family housing construction in Serbia is strongly related to younger contingent of flat occupants.

All respondents clarified that there was one household in their flats. The size of a household varied in both cases. Nevertheless, all of them lived in households of no more than 4 members. The prevalent size of the households was 3-4 members (I - 59\%, II - 45\%), which concurred with the size of a typical nuclear family with children (1-2) in Serbia. The two-member households followed in frequency (I - 26\%; II - 38\%). One-member households were the rarest, albeit still very frequent (I - 15\%; II - 17\%). 
Regarding flat ownership in these buildings, most of the respondents are both dwellers and owners of the flats. Interestingly, this fact was more evident in the second case (II - 93\%) than in the first case (I-81\%). At first sight, these results slightly contradict the essence of the selection process for prospective dwellers in the former housing-funds projects, since the dwellers had to be selected according to their housing needs. Further on, renters were present in both buildings $(I-19 \% ; I I-3 \%)$. Just one person in the second building was a flat occupant without either ownership or rent (she was a friend of the owners).

The survey results: The main core of the questions consists of 14 questions partitioned into three groups. Five questions from group No 1 were the first ever dedicated to the essential research of common space. More precisely, they concern the issue of four collective spaces inside the buildings.

The first four questions (Fig. 8) refer to the respondent's satisfaction with the maintenance of vestibule, the main corridor, staircases, and lift respectively. All indicated elements are defined and regulated by the competent Act on Conditions and Norms for the Design of Residential Buildings and Flats (PS, 2012-2015). In the first three cases, the first building got more positive responses. Full and prevalent satisfaction with collective spaces was registered in $80-90 \%$ responses in the first building and in $70-80 \%$ of them in the second building. In the case of the fourth question, pertained to the maintenance of lift, there was a specific situation in the first building, related to the fact that the lift was very slow. The cuts of building costs related to cheaper and thereby slower lifts were not unusual in many buildings built by solidarity funds. Perhaps the reason can be found in the old standards for these buildings proposed in the socialist time. Therefore, full and overall satisfaction counted $54 \%$ of all the responses. The lift in the second building was "normal", so it obtained a similar level of the respondents' satisfaction as the three aforementioned collective spaces in the same building. Even though the results of the last question were very much influenced by the extraordinary conditions regarding the lift in the first building, they also indicated the fact that this unusual situation could change the respondents' opinion for the worse.

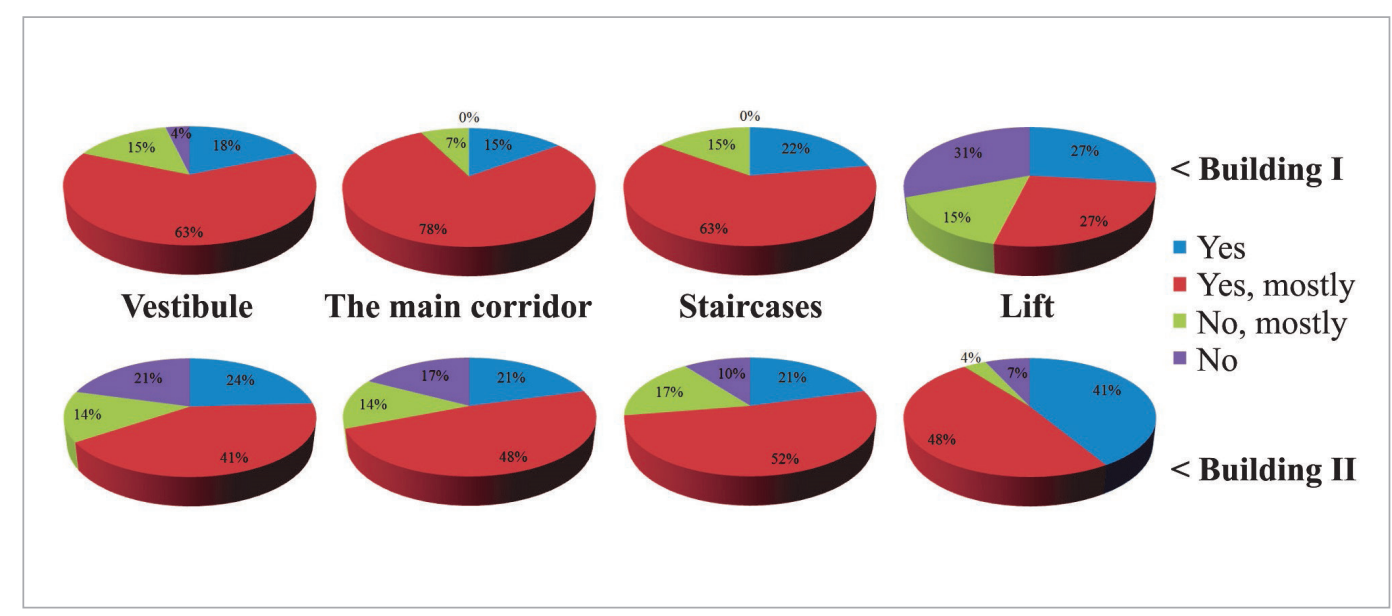

The last question in the first group (Fig. 9) attempts to clarify which of the listed collective spaces should be a priority for future investment. The problem with the lift in the first building made a noticeable impact on the responses. The lift was a priority for $45 \%$ of the respondents. By contrast, the lift was not a priority for the respondents from the second building, where the vestibule was set as the major priority (41\%) for the future. The main corridor and staircases got fewer responses in both cases.

\section{Fig. 8}

The results of the question "Are you satisfied with the maintenance of vestibule / the main corridor / staircase / lift in your building" for both residential buildings (author: Branislav Antonić) 
Fig. 9

The results of the question "What is a priority for future investment in your building?" for the first (left) and the second building (right) (author: Branislav Antonić)
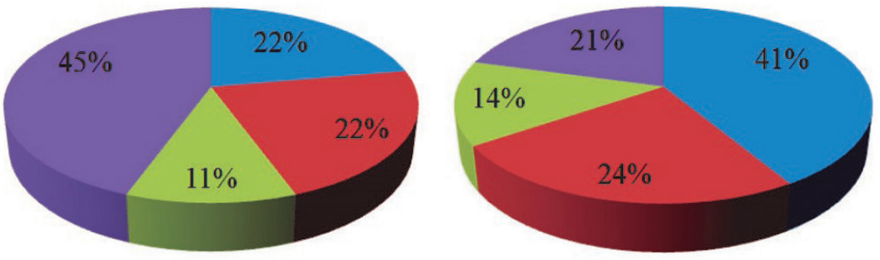

- Vestibule

- The main corridor

- Staircases

- Lift

The second group of questions considers collective spaces around the selected buildings. It has previously been explained that the ownership of indoor collective spaces is a very complex legal matter in Serbia. This situation gets even more complicated when the outdoor collective spaces in open-block structure are concerned. The ownership of a flat in a residential building refers merely to the land below that building. Nevertheless, the dwellers have the right of ordinary use of the nearby land which is designed for these purposes. As a result, they are also responsible for its basic maintenance, at least to some degree (Anđelković, 2011). In practice, this specifically refers to the accompanying parking lots and greenery. Three most relevant collective spaces are separately questioned: the external part in front of the main entrance of the building, the accompanying parking lots, and the greenery around the building (Fig. 10).

\section{Fig. 10}

The results of the question "Are you satisfied with the maintenance of the external part in front of the main entrance of the building / the accompanying parking lots / the greenery around your building?" for both residential buildings (author: Branislav Antonić)

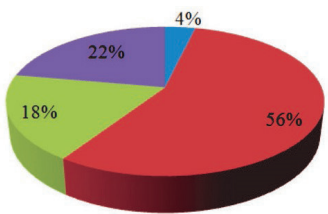

External part in front of the main entrance

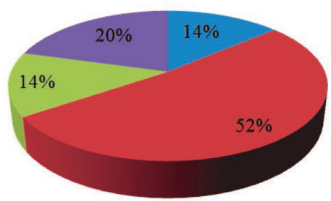

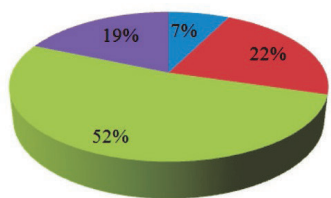

Greenery

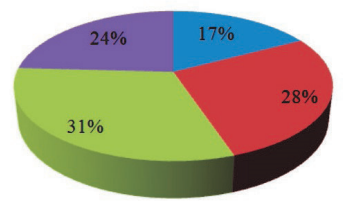

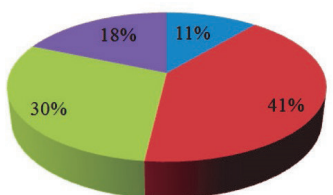

Parking place

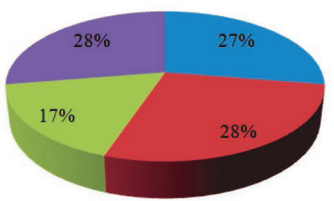

$<$ Building I

- Yes

- Yes, mostly

- No, mostly

- No

$<$ Building II

The respondents' satisfaction regarding these spaces was presented in the first three questions. Equivalent to the questions from the first group, the respondents from the first building responded more positively regarding the maintenance of the external part in front of the main entrance, the parking lot and the green spaces than did the respondents from the second building. The external part in front of the main entrance of the building got positive responses in both cases - more than $60 \%$ of the respondents were fully or mostly satisfied with the maintenance of this external space. The following two questions showed a very different level of satisfaction between the dwellers of the two buildings. The respondents from both buildings had a mostly negative attitude towards the maintenance of the greenery around their building, although the fact was more critical in the first case (I - 71\%; II - 55\%). Finally, in the last issue - the parking lots - both groups of the respondents were satisfied to a similar level. Even though negative and positive responses were similar 
(I - 52\%/48\%; II - 55\%/45\%), the modest responses ("Yes, mostly" and "No, mostly") were more noticeable for the first building (I - 71\%; || - 45\%).

Just like in the case of the first group of questions, the last question (Fig. 11) was dedicated to the priorities for future investment around the building. There were eight options listed and two answers were required. This possibility allows a more diverse scope of responses. Hence, it was expected that the respondents from both buildings would mark very different priorities. In the opinion of those from the first building, the major priorities were a better organization of the garbage space (24\%) and the greenery (28\%). In the opinion of those from the second building, a new playground for children and more parking sites were the most urgent priorities (26\% and $24 \%$, respectively). Interestingly, better pavement and better lightening were the least desirable priorities in both cases.
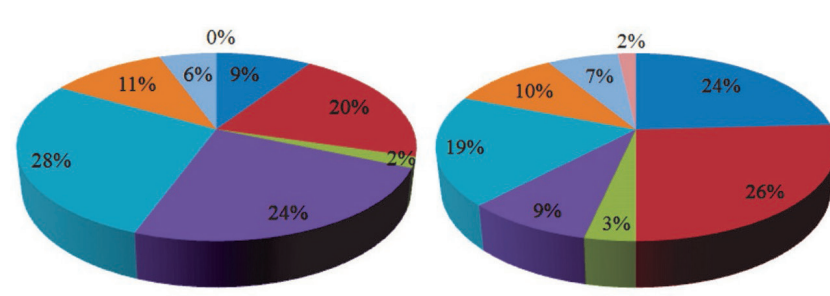

- New playground for children

- More parking spaces

- Better pavement and the access to the building

- Better organised garbage space (Waste containers)

- Better and nicer greenery

- A bench near the entrance

Better lightening

Nothing from the list
Fig. 11

The results of the question "What is a priority for future investment around your building?" for the first (left) and the second building (right) (author: Branislav Antonić)

The third group of questions tried to present the stance of the respondents on their motivation to build a stable and enterprising community in their residential buildings. This question of "community spirit" in condominiums has been the focus of capitalist countries in the West for decades (Friedman, 1962; Castello, 2010). However, this is a novelty for post-socialist countries where different challenges connected to condominiums reappeared with the fall of communism (Tsenkova, 2008; Pojani, Baar, 2016).

This issue was surveyed trough five questions which focused on the ability of the dwellers to improve collective places in and around their buildings. The first question in this group (Fig. 12) tackles the respondents' opinion on the attitude of their neighbours toward collective places in and around their buildings. The answers were similar for both of the buildings. The prevalent answer in both cases proved the dwellers in both buildings to be mostly positive toward collective spaces (I - 59\%; II -55\%). Negative answers were more frequent in the case of the second building.

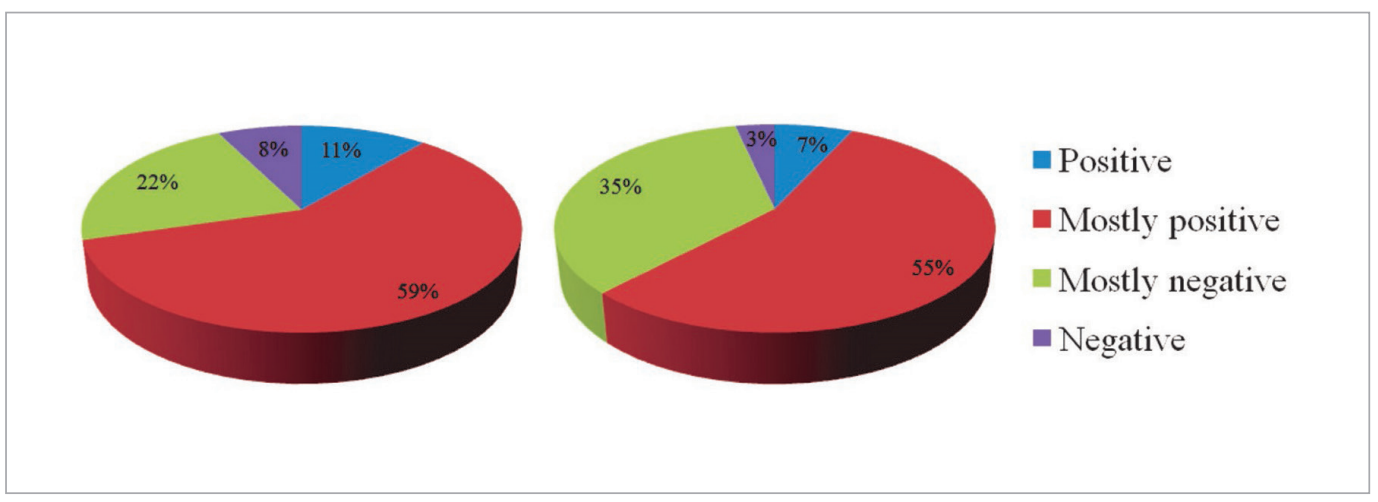

Fig. 12

The results of the question "Which is the prevalent attitude of the building dwellers toward collective spaces in and around your building?" for the first (left) and the second building (right) (author: Branislav Antonić) 
The following two questions were linked with the dwellers' willingness to improve collective spaces in and around the building. In the first question (Fig. 13) the dwellers' willingness was checked independently. The respondents' opinions were noticed to differ on this issue. Most of the respondents from the first building supported the stance that the willingness among their neighbours existed fully or mostly (60\%). By contrast, the respondents from the second building thought that the willingness did not exist among the dwellers (59\%).

Furthermore, extreme answers ("fully exists" or "does not exist") were in line with the previous gap. Almost $1 / 5$ of the first respondents found that the willingness fully existed in their case, whereas almost $1 / 3$ of the second respondents thought that the dwellers' willingness was totally absent in their building. In the second question (Fig. 14) the willingness was confronted to financial expenditure. The respondents had to clarify which of these is a bigger obstacle to the improvement of collective spaces. In both cases majority of the respondents support the standing that both of the mentioned factors are equal obstacles $(I-41 \% ; \|-48 \%)$. Similarly, about $1 / 3$ of the respondents in both buildings saw the dwellers' willingness as a major obstacle for the improvement.

Fig. 13

The results of the question "How do you estimate the willingness of the building dwellers to improve collective places in and around the building?" for the first (left) and the second building (right) (author: Branislav Antonić)

Fig. 14

The results of the question "What is the main obstacle for the improvement of collective places willingness or financial expenditure?" for the first (left) and the second building (right) (author: Branislav Antonić)
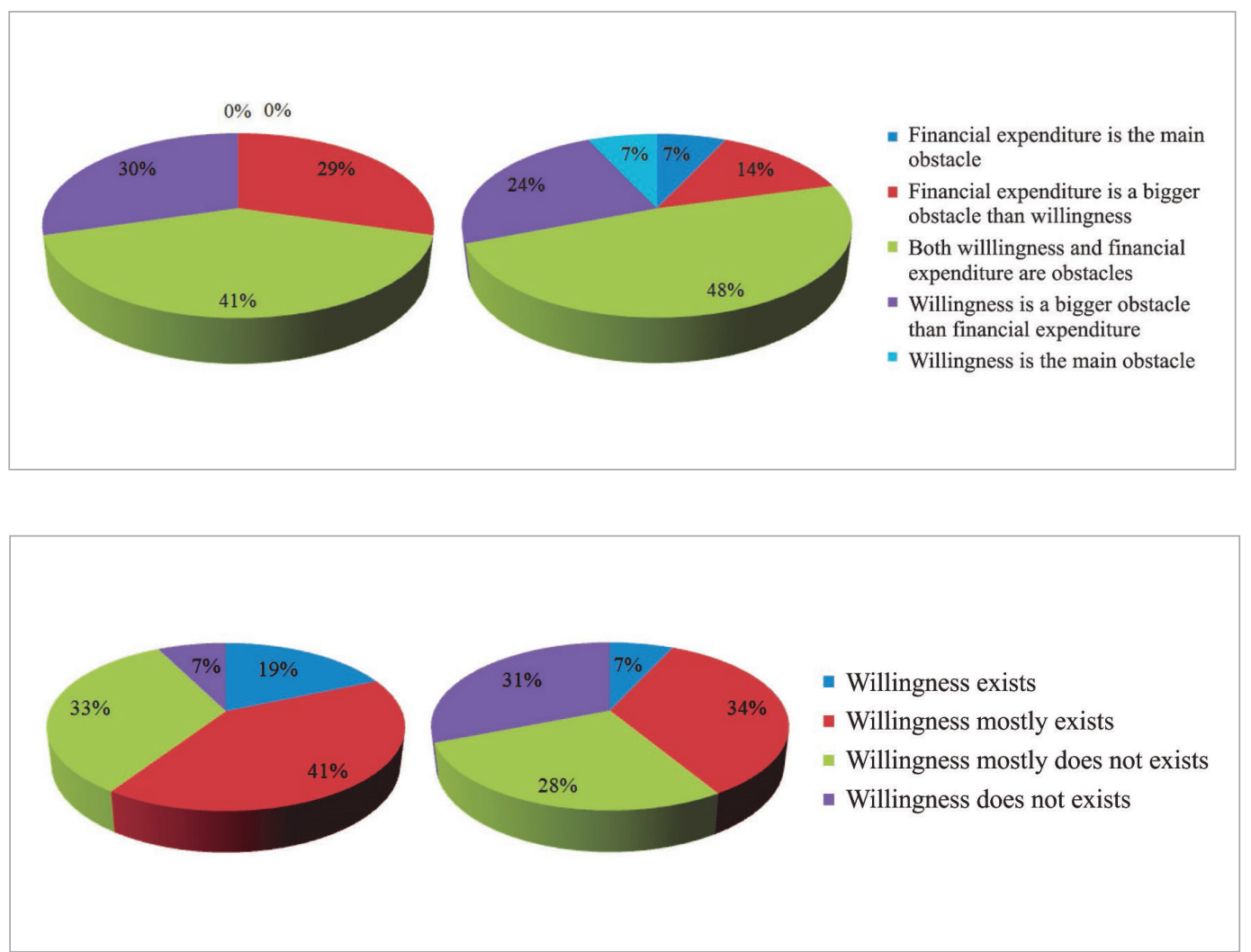

Two last questions (Fig. 15) refer to the roles of the dwellers and city services in the process of collective spaces improvement. Their responsibilities were respectively estimated by the respondents. In the first question the responses were very similar.

The dominant majority in both groups of the respondents (I - 85\%; II - 80\%) thought that mainly dwellers were responsible for the collective spaces in their building. However, when collective spaces around the building were taken into account, the responses differed noticeably. The second group targeted the dwellers (65\%) while the first group targeted city services as the mainly responsible ones (55\%). 


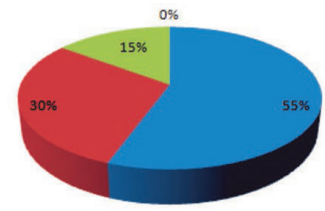

\section{Collective spaces in a building}

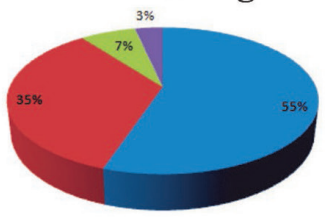

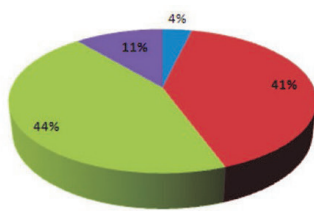

Collective spaces around a building

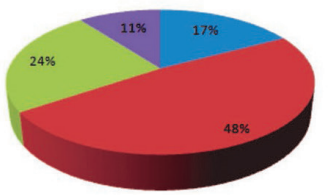

\section{$<$ Building I}

- The building dwellers

- Mainly the building dwellers, than city services

= Mainly city services, than

the building dwellers

- City services

$<$ Building II

The respondents' side reaction on the survey: For more accurate description of the aforementioned results, it is necessary to present some side reactions of the survey respondents. The reason for this is that these reactions further reflect the attitudes of the dwellers of both building towards community space and thereby contribute to the topic of the research.

During the survey in the second building, one of the most obvious problems regarding community building was noticed. Namely, several respondents argued that their building had not formed home council. This housing institution has been obligatory for all multi-family buildings by Yugoslavian/Serbian law for decades. In the same manner, its establishment is obligatory by the acting Law on the Maintenance of Residential Buildings (PS, 1995-2011). Thus, these dwellers believe that the basic element for forming the community does not exist in their building. Hence, it is not strange that some duties which link several flats/households, such as cleaning mutual windows at two corners of the building, have not been performed for years.

By contrast, many respondents in the first building commented that city services did not care enough about collective spaces around their building. One of the results of such a situation was the bad state of greenery around it.

One the other hand, some positive things were visible most of which were in the case of the first building. Here, dwellers have had a well-organized home council for years. In accordance with this, they had organized some small albeit community-important actions. One of these actions was painting the staircase fence. The other was purchasing the colour to paint the garage doors unanimously (a row of garages is situated 30 meters away from the building). For the time being, they intended to buy the same characteristic orange colour to paint the fences of all terraces in the building (similar buildings in vicinity have their own colours). Finally, they were very proud of a table for community information that they had set on their own initiative. All these facts show that the dwellers of the first building have developed a strong "community spirit".

Finally, there were some funny yet indicating situations regarding collective space. For example, the only dog in the first building was not excluded from some common taxes and bills, such as a bill for water and communal electricity (electricity used for collective spaces). Second, one dweller, who lived in the ground floor and therefore did not use upper floors, did not want to pay the full bill for the cleaning of the collective space. In both buildings, the dwellers made negative comments about the bicycles parked in the main corridor, which disturbed comfortable movement through it. 
The main observation regarding the survey results is that the two groups of dwellers do not have very different attitudes toward collective spaces in and around their residential buildings. In more than half of the questions the differences in opted choices between the two groups were very small - they were within $\pm 10 \%$.

However, a thorough examination of the results leads to a somewhat different conclusion. First, it confirms the observation that the respondents from the first building were more satisfied with collective spaces in their building (> 80\%, except in the specific case of the lift). In this case a stable and organized community in the form of a long-lasting and well-coordinated home council has performed a lot of actions inside and around the building.

By contrast, the respondents from the second building exhibited more satisfaction with collective spaces around their building. In this case, the position of the building in the inner centre has made collective spaces around it more visible to public. Such a location of the building has lead to city services taking more care of the collective spaces. Thus, the sociological concept of "eyes on the street" (Jacobs, 1961) is clearly imprinted in this survey. By contrast, the first building is somewhat isolated from the main roads and thereby from general public. Therefore, the maintenance of collective places has probably not been the highest priority of competent city services. Such a situation resulted in more negative answers among the respondents. As a matter of fact, the most problematic answer in the entire survey was the one concerning the maintenance of greenery $-71 \%$ of the respondents were not satisfied with the greenery maintenance.

Further confirmation of the standpoint regarding collective spaces around the buildings can be traced in the answers regarding priorities among these collective places. On one hand, the first group of the respondents opted for the improvement and the better state of the already existing places (better greenery and better garbage place). This is probably due to their thinking that the existing ones were quite sufficient for their building. On the other hand, the second group chose the introduction/ construction of entirely new places (new children playground and more parking places).

The answers to the last group of questions lead to the findings more related to community building in both cases. Even though both groups of the respondents had a similar (and very positive) opinion about the prevalent attitude of their neighbours toward collective places in and around their building, their answers noticeably differ regarding the issue of their willingness and desire to improve these spaces. The answers to the two questions regarding the topic indicate that the dwellers' willingness to improve their collective spaces is stronger in the first building, the one with the established home council. Generally speaking, the results of these questions concurred with the results of the first group of questions.

After the results of the survey have been gathered it has become obvious that some minor differences between the two cases in the survey can indicate more precise considerations about the dwellers' stance to collective places in multi-family housing in the form of a condominium in Serbia and their importance for community building. The different dwellers selection process has an impact on this matter. The social component that is included in the selection process has set a good basis for community building. This is evident in the case of the first residential building. However, small differences in the answers to many questions in this survey also prompt the thinking that community building is possible in other cases, based merely on the economic selection of the dwellers.

The cultivation of "community spirit" is more observable when it is related to indoor community spaces, more related to the dwellers, than to other urban sectors. Furthermore, outdoor collective places are less reliable for this research because the role of other elements in urban space is more evident. Additionally, the question of the building location also plays a significant role. It can influence the entire research. To conclude, this research proves a bigger and extended research 
of this kind to be necessary in order to initially undertake the distinction or the hierarchy between different groups of collective places and their possible importance in and for the urban fabric.

The "cause-consequence" relation can be observed better in relation to the revealed respondents' side reactions during the main procedure of the survey. This information anticipates that a good survey of spatial-related preferences in housing must include the entire "context" of the research. Even unplanned and unusual reactions and comments of the respondents can be useful for a thorough examination of the causes and consequences. However, these side reactions are not valuable individually. Therefore, the research also proposes that qualitative information in housing, which is based on the side reactions of the respondents, should be obtained only if these reactions and comments are linked to the main questions and the results of the survey.

In the end, research results and dissemination clearly prove the maintenance and management of collective spaces in and around condominium buildings to be a complex issue in Serbia as a post-socialist country. The situation with indoor places is better, because their legal status is more regulated and because they are more attached to the dwellers. By contrast, outdoor collective spaces are more problematic. For the examples in open-block structure surveyed within this research, such a situation is the consequence of unsolved legal status of the land around residential buildings, which highly influences the question of their use and maintenance. As a result, outdoor collective spaces should be the focus of any further improvement of housing and ownership legislation and policy. In this prospective process, making the balance between the benefits and the duties for dwellers is a precondition for the rational maintenance and management of these spaces. This topic is even more significant if we know that collective spaces in open residential blocks constitute a substantial part of the open public spaces in many Serbian cities. Thus, it should be included in both agendas, the one on housing and the one on urban policy.

This paper is a part of National research projects No 36034 and No 36035, financed by the Ministry of education and science of the Republic of Serbia.

\section{Acknow- ledgment}

Anđelković Ž. Građa za urbano pravo [Material for Urban Law]. Belgrade: Čigoja; 2011.

Antonić B. 2016. How to understand the history of housing planning in modern Serbia to achieve new quality in housing?, In: C. Hein (ed.) Proceedings of 17th IPHS Conference - Volume 02: The Urban Fabric. Delft: TU Delft - Faculty of Architecture, 165-174. DOI: http://dx.doi.org/ 10.7480/ iphs.2016.2.1234.

Belgrade Housing Agency - BHA. No date. Istorija [History]. Belgrade. Retrieved 10. June 2016. from: http://www.stambeno.com/rs/ view $/$ ? id=3\&ltemid $=16$.

Banks C. O'Leary S. Rabenhorst C. 1996. Privatized Housing and the Development of Condominiums in Central and Eastern Europe: The Cases of Poland, Hungary, Slovakia, and Romania. Review of Urban \& regional Development Studies 8(2): 137-155. DOI: 10.1111/j.1467-940X.1996.tb00114.X. https://doi. org/10.1111/j.1467-940X.1996.tb00114.x
Borén T., Gentile M. 2007. Metropolitan Processes in Post-Communist States: An Introduction. Geografiska Annaler - Series B: Human Geography, 89(2): 95-110. DOI: 10.1111/j.1468-0467.2007.00242.x. https://doi.org/10.1111/j.1468-0467.2007.00242.x

Castello L. Rethinking the Meaning of Place: Conceiving Place in Architecture-urbanism. Farnham: Ashgate; 2010.

City of Sremska Mitrovica - CSM. General Urban Plan of Sremska Mitrovica, Laćarak and mačvanska Mitrovica. Sremska Mitrovica: CSM; 2009

Enyedi, G. 1995. The transition of post-socialist cities. European Review; 3(2): 171-182. DOI: 10.1017/ S1062798700001460. https://doi.org/10.1017/S10627 98700001460

Hamilton I., Dimitrovska Andrews K., Pichler-Milanović N. 2005. Introduction. In: Hamilton I., Dimitrovska Andrews K., Pichler-Milanović N. (eds.) Transformation of cities in central and Eastern Europe: Towards globalization. Tokyo: United Nations

\section{References}


University Press, 3-11. https://doi.org/10.1017/ cbo9780511614835.001

Friedman, H. 1962. Community Apartments: Condominium or Stock Cooperative. California Law Review 50(2): 299-341. DOI: 10.15779/Z38JV2V.

Hegedüs J. 2014. Housing Privatization and Restitution. In: Hegedüs J., Lux M. Teller N. (eds.) Social Housing in Transition Countries. New York - London: Routledge, 33-49.

Hirt, S. Petrović, M. 2011. The Belgrade Wall: The Proliferation of Gated Housing in the Serbian Capital after Socialism. International Journal of Urban and Regional Research 35(4): 753-777. DOI: 10.1111/j.1468-2427.2011.01056.x. https:// doi.org/10.1111/j.1468-2427.2011.01056.x

Hirt S. Stanilov K. Revisiting Urban Planning in the Transitional Countries. Nairobi: UN Habitat; 2009.

Jacobs, J. The Death and Life of Great American Cities. New York: Random House; 1961.

Jovanović Popović M., Ignjatović D., Radivojević A., Rajčić A., Đukanović Lj., Ćuković Ignjatović N., Nedić M. National Typology of Residential Buildings in Serbia. Belgrade: Arhitektonski fakultet and GIZ; 2013.

Jovanović Popović M., Ignjatović D., Radivojević A., Rajčić A., Đukanović Lj., Ćuković Ignjatović N., Nedić M. Atlas of Multifamily Housing in Serbia. Belgrade: Arhitektonski fakultet and GIZ; 2013.

Kemeny, J. 1995. Theories of Power in the Three Worlds of Welfare Capitalism. Journal of European Social Policy 5(2): 87-96. DOI: 10.1177/095892879500500201. https://doi.org/10.1177/095892879500500201

Lux M., Sunega P. 2014. Public Housing in the Post-Socialist States of Central and Eastern Europe: Decline and an Open Future. Husing Studies 29(4): 501-519. DOI: 10.1080/02673037.2013.875986.https://doi.org/ 10.1080/02673037.2013.875986

Milić V. Urbanistički aspekti socijalnog stanovanja [The Urban Planning Aspects of Social Housing]. Belgrade: Arhitektonski fakultet, 2006.

Mojović Đ., Žerjav B. Stanovanje pod zakup [Rental Housing]. Belgrade: Program za urbani razvoj; 2011.

Parliament of Serbia - PS, Закон о основама својинскоправних односа [Law on Fundamentals of Ownership-Legal Relations]. Belgrade: Official Gazette No 6/80, 36/90, 29/96 \& 115/05. 19802005.

Parliament of Serbia - PS, Закон о одржавању стамбених зграда [Law on the Maintenance of Residential Buildings]. Belgrade: Official Gazette No 44/94, 46/98, 1/01, 101/05, 27/11 \& 88/11. 1995-2011.
Parliament of Serbia - PS, Правилник о условима и нормативима за пројектовање стамбених зграда и станова [Act on Conditions and Norms for the Design of residential Buildings and Flats]. Belgrade: Official Gazette No 58/12, 74/15 \& 82/15. 2012-2015.

Petovar K. Urbana Sociologija: Naši gradovi između države i građanina [Urban Sociology: Our Cities between State and Citizen]. Belgrade: Geografski fakultet, Arhitektonski fakultet, IAUS; 2003.

Petrović M. Sociologija stanovanja [Sociology of Housing]. Belgrade: Institut za sociološka istraživanja; 2004.

Petrović, M. Transformacija gradova: Ka depolitizaciji urbanog pitanja [City Transformations: Towards Depolitization of an Urban Question]. Belgrade: Institut za sociološka istraživanja; 2009.

Pichler-Milanović N. Housing Privatisation in Central and Eastern Europe: From Policy to Practice. New York: UN University; 1999.

Pickvance C. 2008. State Socialism. Post-Socialism and their urban Patterns: Theorizing the Central and Eastern European Experience. In: Eade J. Mele C. (eds). Understanding the City. Oxford: Blackwell, 183-203. DOI: 10.1002/9780470693582. ch9. https://doi.org/10.1002/9780470693582.ch9

Pojani D. Baar K. 2016. Multi-family housing management in post-socialist countries: the Albanian experience. Journal of Housing and the Built Environment: 1-18 (published online before printing). DOI:10.1007/s10901-016-9498-1. https://doi. org/10.1007/s10901-016-9498-1

Ramirez L., Mojović Đ., Galassi B., Čolić R. Vuksanović Macura Z. (eds). SIRP Book. Belgrade: UN Habitat; 2008

Sailer-Fliege, U. 1999. Characteristics of post-socialist urban transformation in East Central Europe. GeoJournal, 49(1): 7-16. DOI: Smith, W. F. 1971. Housing: The Social and Economic Elements. Berkeley: University of California Press.

Stenning A. 2005. Post-socialism and the changing geographies of the everyday in Poland. Transactions of the Institute of British Geographers, 30(1): 113-127. DOI: 10.1111/j.1475-5661.2005.00155.x. https://doi.org/10.1111/j.1475-5661.2005.00155.x Tsenkova S. Riga: Housing Policy and Practice - A Framework for Reform. Riga: Riga City Council; 2000.

Tsenkova S. Trends and Progress in Housing Reforms in South Eastern Europe. Paris: Council of Europe Development Bank; 2005. 
Tsenkova, S., Nedović-Budić Z. (eds.) 2006. The urban mosaic of post-socialist Europe: space, institutions and policy. Heidelberg: Springer and Physica-Verlag,

Tsenkova, S. Polanska D. 2014. Between state and market: housing policy and housing transformation in post-socialist cities. GeoJournal, 79(4): 401-405. DOI: 10.1007/s10708-0149538-x. https://doi.org/10.1007/s10708-014$9538-x$
Vujović S. Petrović, M. 2005. O klasičnoj i novoj urbanoj sociologiji [About Classic and New Urban Sociology]. In: Vujović S. Petrović M. (eds). Urbana sociologija [Urban Sociology]. Belgrade: Zavod za udžbenike i nastavna sredstva, 13-68.

Węcławowicz G. Transnational Development Strategy for the Post-Socialist Cities of Central Europe. Warsaw: Polish Academy of Sciences, Institute of Geography and Spatial Organization; 2013.

\section{ALEKSANDRA DUKIĆ}

\section{Associate professor}

University of Belgrade - Faculty of Architecture, Department of Urbanism

\section{Main research area}

Urban design and planning, urban morphology, urban renewal

\section{Address}

Bulevar kralja Aleksandra 73/II,

11000 Belgrade, Serbia

Tel. +381(0)113218753

E-mail: adjukic@afrodita.rcub.bg.ac.rs

\section{BRANISLAV ANTONIĆ}

Researcher-assistant and PhD student

University of Belgrade - Faculty of Architecture, Department of Urbanism

\section{Main research area}

Urban planning, housing, spatial development of small communities

\section{Address}

Bulevar kralja Aleksandra 73/II,

11000 Belgrade, Serbia

Tel. +381(0)113218753

E-mail: antonic83@gmail.com

\section{About the authors}

